\title{
INSTITUTE OF CLASSICAL STUDIES
}

\section{NEW PUB L I C A T I O N S}

BICS Supplement 50

BICS Supplement 62

BICS Supplement 63
Monuments Illustrating New Comedy

By T.B.L. Webster

Third edition revised and enlarged by J.R. Green and Axel Seeberg

Vol. $1 \mathrm{xv}+384$ pages +59 plates

Vol. $2 x+518$ pages

ISBN 0900587768 the set

The Dancing Maenad Reliefs

$£ 35$ By Lori-Ann Touchette

$x+119$ pages +56 plates

ISBN 0900587652

Klados: Essays in Honour of J.N. Coldstream Edited by Christine Morris

$\mathrm{xii}+310$ pages, figures and plates throughout text

ISBN 0900587660

All Institute publications may be ordered from Mrs Catherine Crabb, Publications Officer, Institute of Classical Studies, 31-34 Gordon Square, London WC1H OPY, fax 01713834807 . A full list of books in print is available on request. Please do not send money with your order; an invoice will be sent to you. 


\title{
THE SOCIETY FOR THE PROMOTION OF HELLENIC STUDIES
}

\section{GORDON SQUARE, LONDON WC1H OPP}

\section{HONORARY MEMBERS}

\author{
Akurgal, Professor E., Ankara, Turkey \\ Amandry, Professor Pierre, Paris, France \\ Bothmer, Dr Dietrich von, New York, USA \\ Buchner, Dr Giorgio, Porto d'Ischia, Italy \\ Burkert, Professor Dr W., Uster, Switzerland \\ Dihle, Professor Albrecht, Heidelberg, Germany \\ Dover, Sir Kenneth, St Andrew's, Scotland \\ Irigoin, Professor Jean, Paris, France \\ Karageorghis, Dr V., Nicosia, Cyprus \\ Karouzou, Mrs S. P., Athens, Greece \\ Kassel, Professor R., Cologne, Germany \\ Knox, Professor B. M. W., Darnestown, Maryland, USA \\ Koumoulides, Professor John T., Muncie, Indiana, USA \\ Kunze, Dr E., Grosshesselohe bei München, Germany \\ Ostwald, Professor Martin, Swarthmore, Pennsylvania, USA \\ Platon, Dr N., Athens, Greece \\ Pritchett, Professor W.K., Berkeley, California, USA \\ Pugliese Carratelli, Professor G., Rome, Italy \\ Raubitschek, Professor A.E., San Francisco, California, USA \\ Reverdin, Professor Olivier, Geneva, Switzerland \\ Romilly, Professor J. de, Paris, France \\ Thompson, Mrs D. B., Princeton, New Jersey, USA \\ Thompson, Professor Homer A., Princeton, New Jersey, USA \\ Trendall, Professor A. D., Bundoora, Victoria, Australia \\ Vernant, Professor F., Sèvres, France \\ Vian, Professor F., Versailles, France \\ Vokotopoulou, Dr Julia, Thessalonike, Greece \\ Will, Professor E., Nancy, France
}

\section{CORPORATE MEMBERS}

BANK OF CYPRUS (LONDON) LTD

CAPESIDE STEAMSHIP COMPANY LTD

CHANDRIS (LONDON) LTD

CHARLES EDE LTD

JOHN A. HADJIPATERAS, ESQ.
JOHN C. HADJIPATERAS \& SONS, LTD. LEVENTIS OVERSEAS LTD

SOTHEBY'S

SWAN HELlENIC

VICTORIA STEAMSHIP CO. Ltd

\section{Hellenic and Roman Societies \\ SLIDES COLLECTION}

The Slides Collection contains over 6,600 coloured $35 \mathrm{~mm}$ slides covering a wide variety of subjects, including sites on the Greek mainland, the Greek islands, Cyprus, Rome, Italy and the Roman Empire, Etruscan tomb paintings, Greek vases, Roman frescoes and mosaics, the Roman army and Roman Britain. Slides of artefacts form a large part of the collection and include bronzes, jewellery and vases as well as maps, plans, models and reconstructions.

Catalogues: Greek Slides (1993): £8; Roman Slides (1994) £7; both for $£ 11$ (postage $£ 1$ extra for each volume)

Individual slides, sets and filmstrips with notes may be hired by members. Filmstrips are also available for sale to members and non-members. Details of current charges may be obtained from the Keeper of Slides. 


\section{The Society for the Promotion of Hellenic Studies}

31-34 GORDON SQUARE, LONDON WC1H OPP

PRESIDENT: PROFESSOR E.W. HANDLEY, CBE, FBA, HON. RA The Society was founded in 1879 to advance the study of Greek language, literature, history, art and archaeology. It has doen this ever since by various means, chief among them being the annual publication of the Journal of Hellenic Studies, and, since the 1950s, its supplement, Archaeological Reports, which are both supplied free of charge to members of the Society. Occasional monographs also appear in the series Supplementary Papers.

The Society also helps to maintain the Joint Library at 31-34 Gordon Square. in conjunction with the Roman Society and the Institute of Classical Studies of the University of London. Membership of the Hellenic Society allows the reader to borrow up to four books at a time, either in person or by post (within the UK). Members may also borrow slides from the Joint Library's extensive collection.

The Society also arranges an annual lecture series in London and helps to support other lectures throughout the UK in collaboration with the various local branches of the Classical Association. The Society aims to help those engaged in Hellenic Studies at all levels and to this end it makes grants to schools, colleges and universities; small grants to individual students are also available.

Membership is open to all, and there is a reduced rate for full-time students. Subscriptions are due on January 1 each year. 1995 and 1996 rates are as follows: full members $£ 27$ (US $\$ 60$ ), student associates $£ 15$, corporate members $£ 150$, libraries (rates include postage): $£ 41$ (US $\$ 90$ ). Life membership ( $£ 135$ ) is available to those over 65 years of age, after 5 years ordinary membership.

\section{Hellenic Society Publications}

Back Numbers of THE JOURNAL OF HELLENIC STUDIES and ARCHAEOLOGICAL REPORTS may be ordered from the Society office; price list and availability on request.

THE JHS INDEX TO VOLUMES LXI-XC (1941-70) compiled by J.O. Burtt $£ 8$ or $\$ 18$

THE JHS INDEX TO VOLUMES XCI-CX (1971-90) compiled by Janet Hamilton $£ 20$ or $\$ 40$

\section{Supplementary Papers}

9. THE GREEK ANTHOLOGY: SOURCES AND ASCRIPTIONS by A.S.F. Gow (1958)

11. EURIPIDES AND THE JUDGEMENT OF PARIS, by T.C.W. Stinton (1965)

12. THE SANTORINI VOLCANO AND THE DESOLATION OF MINOAN CRETE, by D.L. Page (1970)

13. EAST GREEK INFLUENCE ON ATTIC VASES, by D.A. Jackson (1976)

14. ATTIKA - STUDIES IN ATHENIAN SCULPTURE OF THE HELLENISTIC AGE, by A. Stewart (1979) $£ 12$ or $\$ 26$

15. PAPERS ... ON GREEK DRAMA IN HONOUR OF R.P. WINNINGTON-INGRAM (1986)

$$
\text { Prices include surface mail postage }
$$

Members of the Society are offered a 10\% discount on all publications other than the current $J H S$ and AR; new members are offered a discount of $20 \%$ during their first year of membership.

For all further details, and application forms, please contact:

The Secretary, Hellenic Society, 31-34 Gordon Square, London WC1H OPP, UK

(telephone/fax 0171387 7495, Email helsoc@clus1.ulcc.ac.uk)

\section{The Society for the Promotion of Roman Studies}

31-34 GORDON SOUARE, LONDON WC1H OPP

President: DR AVERIL M. CAMERON, FBA, FSA The Society, founded in 1910 and based in London, is the leading organization for all those interested in the study of Rome and the Roman Empire. Its scope is wide, covering Roman history, archaeology, literature and art down to about A.D.700. It has a broadly based membership, drawn from over 25 countries and from all ages and walks of life. The Society publishes the Journal of Roman Studies, which deals with the Roman world in general, and also Britannia, a journal of Romano-British and connected studies, which includes an annual survey of Romano-British excavations.

The Society maintains with the Hellenic Society and in conjunction with London University's Institute of Classical Studies a joint library of works on classical antiquity and a collection of slides and film strips. Members resident in or visiting the U.K. may borrow books and slides and consult books belonging to the Institute. Meetings of the Society are held in London and in other parts of the U.K. together with other societies. Triennial conferences with the Hellenic Society and the Classical Association are held in either Oxford or Cambridge.

Annual subscriptions: Members and Schools, $£ 25$ (US \$50) for either the JRS or Britannia ( $£ 40$ (US \$80) for both). Institutions other than Schools, $£ 30$ (US $\$ 60$ ) for each publication. Students, $£ 15$ (US $\$ 30$ ) - student membership is open to students registered at any institution of higher education in any country. Life membership for members over 65 with five years' membership, £125 (US \$250).

All enquiries to the Secretary. Telephone 0171-387-8157; Email: romansoc@clus1.ulcc.ac.uk

\section{The Classical association}

The Classical Association has a worldwide membership and is open to all who value the study of the languages, literature and civilisations of ancient Greece and Rome. It creates opportunities for friendly exchange and co-operation among classicists, encourages scholarship through its journals and other publications, and supports classics in schools and universities. Every year it holds an annual conference, and sponsors branches all over the country which put on programmes of lectures and other activities.

The Classical Association has about 4,000 members. The annual subscription is $£ 5$, life membership is $£ 105$. Members receive Proceedings of the Classical Association once a year and a newsletter, CA News, twice a year. They may also subscribe at substantially reduced cost to the Classical Association journals Classical Quarterly. Classical Review', and Greece and Rome.

Applications for membership and subscriptions (cheques payable to 'The Classical Association') should be sent to the Treasurer, Richard Wallace, Dept. of Classics, Keele University, Newcastle under Lyme, Staffs ST5 5BG. The Treasurer can also give information about journal subscription rates, and about the Association's other publications, including the Greece and Rome supplements New' Surveys in the Classics.

Contributions to the Journal should be sent to Dr R.L. Hunter, Pembroke College, Cambridge CB2 1RF. Please send photocopies or printout, retaining original copy. A style guide is printed in JHS vol. 110 (1990) 295-96. Copy on computer disk is preferred, but please send disks only when your contribution has been accepted. Illustrations, including diagrams, must be supplied as camera-ready copy. For further details, please contact the Production Editor (Society address). Books for review should be addressed to the Librarian (Society address). The Journal does not accept unsolicited book reviews. 